\title{
INTERNALISASI NILAI ANTIKORUPSI MELALUI PENCEGAHAN DAN PENGENDALIAN BENTURAN KEPENTINGAN DI PERGURUAN TINGGI
}

\author{
Beni Kurnia Illahi \\ Fakultas Hukum Universitas Bengkulu \\ beniillahi@yahoo.co.id
}

\begin{abstract}
One of the factors driving the corruption emergence is the existence of a conflict or conflict of interest. That is why, this research aims to describe this matter, and that in fact the problems of corruption it is time to start from the upstream by incorporating anti-corruption values through the prevention and control of conflicts of interest, especially in Higher Education institutions. The type that will be used in this research is normative legal research, where this research is carried out by examining literature or secondary data. Regulations related to conflicts of interest have been regulated through Minister of Research, Technology and Higher Education Regulations on Handling Conflicts of Interest. However, with various shortcomings, the regulation has not been able to fully accommodate the dynamics that occur due to conflicts of interest. It needs more detailed rules to identify how much the impact of the conflict of interest is bad for the University. In order to incorporate anti-corruption values through the prevention and control of conflicts of interest in tertiary institutions, one of the approaches we must use today is the normative and ethical approach. The approach can be in the form of harmonizing and synchronizing the norms governing conflicts of interest, identifying typologies of conflict of interest in tertiary institutions through the preparation of detailed norms derived from the lowest rule, and developing conflict of interest prevention tools by establishing a complaints and settlement system at University.
\end{abstract}

Keywords: Anticorruption; Conflict of Interest; Internalization; University; Value;

\begin{abstract}
Abstrak
Salah satu faktor pendorong munculnya tindak pidana korupsi itu adalah adanya benturan atau konflik kepentingan. Itu sebabnya, penulisan ini bertujuan untuk menelusuri hal tersebut, dan bahwa sebenarnya persoalan-persoalan korupsi itu sudah saatnya dimulai dari hulu dengan memasukkan nilai-nilai antikorupsi melalui pencegahan dan pengendalian konflik kepentingan terutama pada instansi Perguruan Tinggi. Jenis yang akan digunakan dalam penelitian ini adalah penelitian hukum normatif (yuridis normative), dimana penelitian ini dilakukan dengan cara meneliti bahan pustaka atau data sekunder. Sebetulnya regulasi terkait konflik kepentingan sudah diatur melalui Peraturan Menteri Riset, Teknologi dan Pendidikan Tinggi tentang Penanganan Benturan Kepentingan. Namun, dengan berbagai kekurangan yang ada, regulasi tersebut belum mampu mengakomodir secara utuh dinamika-dinamika yang terjadi yang disebabkan oleh konflik kepentingan. Sehingga perlu aturan yang lebih rinci untuk mengidentifikasikan seberapa besar dampak konflik kepentingan itu berdampak buruk bagi lingkungan di Perguruan Tinggi. Dalam rangka memasukkan nilai-nilai antikorupsi melalui pencegahan dan pengendalian konflik kepentingan di Perguruan Tinggi, maka salah satu pendekatan yang harus kita gunakan saat ini adalah pendekatan normatif dan etis. Pendekatan tersebut dapat berupa melakukan harmonisasi dan sinkronisasi terhadap norma-norma yang mengatur terkait konflik kepentingan, mengidentifikasi tipologi-tipologi konflik kepentingan di Perguruan Tinggi melalui penyusunan turunan norma yang detail pada
\end{abstract}

Beni Kurnia Illahi, Internalisasi Nilai Antikorupsi Melalui Pencegahan Dan Pengendalian Benturan Kepentingan Di Perguruan Tinggi 
Supremasi Hukum : Jurnal Penelitian Hukum

p-ISSN: 1693-766X ; e-ISSN: 2579-4663, Vol. 28, No. 2, Agustus 2019, 135-152

aturan terendah, serta menyusun tools pencegahan konflik kepentingan dengan membentuk sistem pengaduan dan penyelesaian kasus di level pimpinan Perguruan Tinggi.

Kata Kunci: Antikorupsi; Benturan Kepentingan; Internalisasi; Perguruan Tinggi; Nilai;

\section{PENDAHULUAN}

Pelibatan unsur civitas academica dalam gerakan pemberantasan korupsi tentu saja akan menambah amunisi baru dalam perang besar menyelamatkan negara dari praktik congkak korupsi. Namun, hal tersebut akan menjadi utopis ketika civitas academica Perguruan Tinggi juga turut serta menggadaikan seluruh prinsip Tri Dharma Perguruan Tinggi demi bisnis dengan meraup sebuah keuntungan. Beberapa kalangan bahkan mengatakan bahwa tindakan rasuah yang terjadi di Perguruan Tinggi dinilai sebagai suatu kejahatan kerah putih (white collar crime), karena dilakukan oleh orang-orang terdidik dan terpelajar, memegang kekuasaan, dan mempunyai akses sumber daya ekonomi yang sangat besar.

Berdasarkan kajian Komisi Pemberantasan Korupsi RI ada 4 (empat) faktor sebetulnya penyebab pengelolaan anggaran pendidikan di Perguruan Tinggi itu menuai masalah, diantaranya lemahnya pengendalian internal, tidak terkontrolnya sistem administrasi dan ketatausahaan, adanya kekosongan pengawasan, dan lemahnya upaya pengawasan baik internal maupun ekternal. ${ }^{1}$ Keempat faktor ini tentu saja berpotensi menyuburkan korupsi disegala lini. Karena, kalau bicara soal dampak korupsi di sektor pendidikan tidak hanya pada pemborosan yang merugikan keuangan negara, namun lebih luas dari itu korupsi di sektor pendidikan (termasuk Perguruan Tinggi) akan merusak kredibilitas dan integritas penyelenggara pendidikan sebagai organ yang melahirkan bibit-bibit generasi muda potensial dan berprestasi.

Secara konstitusional, Pasal 31 ayat (1) UUD NRI Tahun 1945 telah mengamanatkan bahwa setiap warga Negara berhak mendapatkan pendidikan. Namun langgam konstitusi terkait pendidikan ini tampaknya sering terlanggar dengan banyaknya modus operandi atau pola korupsi yang dilakukan langsung oleh oknum unsur Perguruan Tinggi tersebut. Diantaranya yaitu korupsi di sektor pengadaan barang dan jasa. Jika dirangking kasus korupsi di Perguruan Tinggi tersebut, korupsi di sektor pengadaan barang dan jasa meraih peringkat paling atas. Rasionya, dari 37 kasus korupsi yang terungkap ke publik, sebanyak 14 kasus diantaranya adalah korupsi di sektor pengadaan barang dan jasa yang nilai kerugiannya mencapai miliaran bahkan triliunan rupiah. ${ }^{2}$

Meskipun korupsi di sektor pengadaan barang dan jasa memegang rekor tertinggi pada Perguruan Tinggi, tetapi tindakan koruptif berupa penyalahgunaan wewenang dalam penerimaan mahasiswa baru juga turut merusak sistem pengelolaan Perguruan Tinggi di Indonesia. Nilai suapnya bahkan bisa mencapai

1 Laras Susanti, Bunga Rampai Makalah Anti Corruption Summit 2016, Yogyakarta: Pusat Kajian Anti Korupsi (PUKAT Korupsi) Universitas Gadjah Mada, 2016, hlm.119

2 Indonesia Corruption Watch, Penerapan Unsur Merugikan Keuangan Negara Dalam Delik Tindak Pidana Korupsi, Jakarta: Indonesia Corruption Watch, 2014, hlm. 3

Beni Kurnia Illahi, Internalisasi Nilai Antikorupsi Melalui Pencegahan Dan Pengendalian Benturan Kepentingan Di Perguruan Tinggi 
Supremasi Hukum : Jurnal Penelitian Hukum

p-ISSN: 1693-766X ; e-ISSN: 2579-4663, Vol. 28, No. 2, Agustus 2019, 135-152

ratusan juta rupiah. Pada tingkat Universitas ataupun Institut, tindakan tersebut kerap terjadi pada tahapan Seleksi Mandiri Masuk Perguruan Tinggi Negeri (SMMPTN). Salah satu modus yang digunakan adalah menambah kuota mahasiswa di jalur SMMPTN tersebut. Di mana dalam tahapan pengumuman kelolosan, ternyata ada perbedaan jumlah kuota diawal yang akan terima dengan jumlah yang secara resmi diumumkan. Artinya, ada upaya penambahan kuota yang dilakukan oleh Perguruan Tinggi secara diam-diam diakhir pengumuman kelulusan dengan tidak didasari pertimbangan ataupun alasan hukum yang logis. Selain korupsi di sektor pengadaan barang dan jasa dan penambahan kuota illegal dalam penerimaan mahasiswa baru, sebetulnya masih banyak modus atau pola perilaku-perilaku koruptif yang mayoritas terjadi pada perguruan tinggi, seperti tindakan menyimpang dalam penelitian dan pengabdian masyarakat yang berindikasi memperkaya diri sendiri tanpa menghasilkan output yang bermanfaat, hinga perbuatan curang dan nepotisme dalam rekrutmen dan pengangkatan tenaga kepegawaian juga turut memprihatinkan kondisi pengelolaan Perguruan Tinggi di Indonesia.

Berdasarkan kondisi tersebut, ternyata betul prediksi dari banyak kalangan dan pelbagai literatur yang mengatakan bahwa salah satu faktor pendorong munculnya tindak pidana korupsi itu adalah benturan atau konflik kepentingan. Itu sebabnya, dalam hal ini penulis ingin menelusuri sebenarnya persoalanpersoalan korupsi itu sudah saatnya dimulai dari hulu dengan memasukkan nilainilai antikorupsi melalui pencegahan dan pengendalian konflik kepentingan terutama pada instansi Perguruan Tinggi. Akan tetapi menentukan sebuah perbuatan mengandung konflik kepentingan bukanlah suatu perkara yang mudah. Perlu irisan ataupun batasan instrument yang jelas dalam mengelola konflik kepentingan tersebut. Sehingga upaya pencegahan dan pemberantasan tindak pidana korupsi dapat berjalan maksimal.

Dalam rangka pencegahan tindak pidana korupsi, jika pengelolaan konflik kepentingan itu dikelola secara baik melalui penormaan hukum dan pendekatan secara etis, maka masyarakat, penyelenggara negara, korporasi, dan stakeholders terkait, dapat membaca dan memahami kapan suatu perbuatan itu dikatakan konflik kepentingan. Karena, pada hakikatnya konflik kepentingan itu belum tentu korupsi atau kecurangan, tetapi ia dapat memicu penyalahgunaan kewenangan untuk keuntungan pribadi dan mungkin mengandung potensi perilaku yang menyimpang.

Di level perguruan tinggi sendiri sebetulnya regulasi terkait konflik kepentingan sudah diatur melalui Peraturan Menteri Riset, Teknologi dan Pendidikan Tinggi Nomor 58 Tahun 2016 tentang Penanganan Benturan Kepentingan. Namun, dengan pelbagai kekurangan yang ada, menurut hemat penulis, regulasi tersebut belum mampu mengakomodir secara utuh dinamikadinamika yang terjadi yang disebabkan oleh konflik kepentingan. Perlu aturan yang lebih rinci sesungguhnya untuk mengidentifikasikan seberapa besar dampak konflik kepentingan itu berdampak buruk bagi lingkungan di Perguruan Tinggi. Dalam rangka memasukkan nilai-nilai antikorupsi melalui pencegahan dan pengendalian konflik kepentingan di Perguruan Tinggi, maka salah satu

Beni Kurnia Illahi, Internalisasi Nilai Antikorupsi Melalui Pencegahan Dan Pengendalian Benturan Kepentingan Di Perguruan Tinggi 
Supremasi Hukum : Jurnal Penelitian Hukum

p-ISSN: 1693-766X ; e-ISSN: 2579-4663, Vol. 28, No. 2, Agustus 2019, 135-152

pendekatan yang harus kita gunakan saat ini adalah pendekatan normatif dan etis. Pendekatan tersebut dapat berupa melakukan harmonisasi dan sinkronisasi terhadap norma-norma yang mengatur terkait konflik kepentingan, mengidentifikasi tipologi-tipologi konflik kepentingan di Perguruan Tinggi melalui penyusunan turunan norma yang detail pada aturan terendah, serta menyusun tools pencegahan konflik kepentingan dengan membentuk sistem pengaduan dan penyelesaian kasus di level pimpinan Perguruan Tinggi. Karena melakukan harmonisasi dan membentuk turunan suatu norma tidak bisa hanya sekedar mengidentifikasi dari aspek aturan hukum nasional saja, untuk memperkaya substansi dan ruang lingkup dari konflik kepentingan tersebut, maka perlu juga memperbandingkan dengan instrument hukum internasional yang juga mengatur soal konflik kepentingan.

\section{METODE PENELITIAN}

Penelitian hukum dibedakan atas penelitian hukum normatif dan penelitian hukum empiris. Jenis yang akan digunakan dalam penelitian ini adalah penelitian hukum normatif (yuridis normative). Alasannya, penelitian ini dilakukan dengan cara meneliti bahan pustaka atau data sekunder ${ }^{3}$

Dari segi sifat, penelitian ini merupakan penelitian deskriptif (descriptive reseach). Penelitian deskriptif adalah suatu penelitian untuk melukiskan tentang sesuatu hal dalam ruang dan waktu tertentu. Dalam penelitian hukum, penelitian deskriptif ini sangat penting untuk menyajikan bahan-bahan hukum yang ada secara tepat, di mana sesuai bahan-bahan itulah preskripsi hukum disusunkan.Sedangkan dari sudut pandang bentuk, tipe penelitian ini adalah penelitian preskriptif. Penelitian yang bertujuan untuk memberikan gambaran atau merumuskan masalah sesuai dengan keadaan/fakta yang ada. Sifat perskriptif ini akan digunakan untuk menganalisis dan menguji nilai-nilai yang terdapat dalam hukum. Adapun data yang digunakan dalam penelitian ini adalah data sekunder. Dalam penelitian hukum, data sekunder mencakup : bahan hukum primer, bahan hukum sekunder dan bahan hukum tersier. Bahan hukum primer berupa UUD 1945 sebelum dan setelah perubahan, UU Penyelenggaraan Negara Yang Baik dan Bersih dan Peraturan perundang-undangan terkait. Adapun bahan hukum sekunder berupa karya ilmiah, buku, dan informasi cetak maupun elektronik yang relevan dengan masalah penelitian ini.

\section{HASIL DAN PEMBAHASAN}

\section{Konsep Dasar Pengelolaan Benturan Kepentingan}

Dalam perkembangan kehidupan manusia yang makin kompleks, standar hukum dinilai tidak lagi cukup untuk memperbaiki keadaan. Semakin hukum dibuat dalam rupa yang makin canggih, pelanggarannya pun berkembang melebihi daya jangkau hukum itu sendiri. Kondisi inilah kemudian yang mendasari para

${ }^{3}$ Soekanto, Soerjono., Faktor-Faktor yang Mempengaruhi Penegakan Hukum, Jakarta: Raja Grafindo Persada, 2006, hlm. 13.

Beni Kurnia Illahi, Internalisasi Nilai Antikorupsi Melalui Pencegahan Dan Pengendalian Benturan Kepentingan Di Perguruan Tinggi 
Supremasi Hukum : Jurnal Penelitian Hukum

p-ISSN: 1693-766X ; e-ISSN: 2579-4663, Vol. 28, No. 2, Agustus 2019, 135-152

pemikir sosiologi hukum untuk menjustifikasi bahwa hukum selalu tertinggal dari perkembangan masyarakat. Oleh karena itu, menyandarkan perbaikan keadaan kepada semata-mata hukum, tentunya akan berujung dengan kekecewaan. Agar harapan pada hukum dapat dicapai, hukum mesti dilengkapi dengan standar yang melampauinya, yaitu standar moral dan etika. Secara hakiki sebetulnya konflik kepentingan merupakan persoalan moral dan etika yang tidak bisa dipisahkan dari ruang dan waktu. Itu sebabnya, stadar moral dan etika lah yang kemudian dapat dijadikan tameng dalam pengelolaan benturan kepentingan tersebut. Hal tersebut semakin meyakinkan ketika Duncan Williamson mengutip definisi benturan kepentingan (conflict of interest) dari tulisan Mc Donald yang mendefinisikan bahwa konflik kepentingan merupakan suatu situasi dalam mana seseorang, seperti petugas publik, seorang pegawai, atau seorang profesional, memiliki kepentingan privat atau pribadi dengan mempengaruhi tujuan dan pelaksanaan dari tugas-tugas kantornya atau organisasinya.

Sementara menurut perspektif penulis benturan atau konflik kepentingan itu merupakan sebuah situasi yang menggambarkan seorang penyelenggara negara bertindak bertentangan dengan tanggungjawab atau fungsinya demi mendapatkan keuntungan pribadi atau memanfaatkan relasi-relasi untuk keuntungan pribadi, yang umumnya berupa uang. Lazimnya, dalam relasi tertentu, individu-individu mempercayakan seseorang untuk bertindak tanpa batas demi kepentingan terbaiknya. Ketika seseorang memiliki tanggungjawab untuk mewakili orang lain, baik sebagai administrator, eksekutor, penuntut umum, pembela maupun pejabat pemerintah, benturan antara tanggungjawab profesional dan kepentingan pribadi akan mengemuka ketika orang tersebut berusaha untuk bekerja secara profesional sambil mengupayakan keuntungan pribadinya. 4

Sebetulnya konflik kepentingan bukan hanya terjadi antara kepentingan pribadi dan tanggungjawab profesional, melainkan sesama tanggungjawab professional, misalnya seorang konsultan hukum melayani dua klien atau seorang pejabat memimpin lebih dari satu organisasi. Ia tidak akan dapat bertindak adil ketika secara aktual maupun potensial kepentingan kedua orang atau organisasi tersebut berseberangan. Jika kita persempit cakupan definisi konflik kepentingan dalam jagat ilmu hukum misalnya, maka konflik kepentingan dapat diartikan masuknya kepentingan pribadi ke dalam tindakan/kebijakan publik, yang dapat menimbulkan kerugian bagi negara sebagai subjek hukum baik secara materiil maupun imateriil.

Dari definisi diatas dan pelbagai tindak-tanduk seseorang melakukan konflik kepentingan selama ini, maka sudah sepatutnya para pemikir dari seluruh disiplin ilmu menentukan dan menyeragamkan unsur-unsur apa yang harus dipenuhi sehingga seseorang itu dapat dikatakan masuk dalam situasi lingkaran

4 Transparency International Indonesia, Naskah Akademik Peraturan Menteri Riset, Teknologi, dan Pendidikan Tinggi tentang Pencegahan dan Pengendalian Konflik Kepentingan di Perguruan Tinggi Negeri, Jakarta: Transparency International Indonesia 2018 : 59

Beni Kurnia Illahi, Internalisasi Nilai Antikorupsi Melalui Pencegahan Dan Pengendalian Benturan Kepentingan Di Perguruan Tinggi 
Supremasi Hukum : Jurnal Penelitian Hukum

p-ISSN: 1693-766X ; e-ISSN: 2579-4663, Vol. 28, No. 2, Agustus 2019, 135-152

konflik kepentingan. Menurut penulis ada beberapa unsur untuk mengidentifikasi situasi konflik kepentingan tersebut, Pertama, adanya unsur penyalahgunaan wewenang oleh penyelenggara negara yang dilakukan atas kepentingan pribadi (private interests). Dikarenakan jabatan yang melekat pada dirinya, sehingga ia dapat mempengaruhi kualitas dan kinerja yang seharusnya. Kedua, adanya hubungan atau afiliasi yang dimiliki oleh penyelenggara negara dengan pihak tertentu baik karena hubungan darah, hubungan perkawinan maupun hubungan pertemanan. Sehingga dengan adanya afiliasi tersebut maka dapat mempengaruhi keputusan penyelenggara Negara untuk melakukan sesuatu yang sejatinya bertentangan dengan etika dan peraturan perundang-undangan. Ketiga, terdapatnya akses khusus yang diberikan oleh penyelenggara negara kepada pihak tertentu tanpa mengikuti prosedur yang seharusnya. Misalnya dalam pengisian jabatan struktural pada instansi pemerintah yang sarat akan politik, proses pengadaan barang dan jasa yang tidak transparan dan akuntabel, hingga tindakan post employment berupa trading influence yang menyangkut rahasia jabatan penyelenggara negara. Keempat, menyangkut kebijakan diskresi yang menyalahgunakan wewenang tanpa mengakomodir peraturan perundangundangan yang berlaku.

Meskipun hanya empat unsur umum yang penulis nukilkan dalam mengindentifikasi sebuah konflik kepentingan, namun empat unsur ini setidaknya dapat mewakilkan seluruh tipologi-tipologi konflik kepentingan. Empat unsur inilah yang kemudian diturunkan secara terperinci baik melalui norma hukum maupun dalam bentuk petunjuk pelaksana dan petunjuk teknis (JUKLAK-JUKNIS) terhadap bentuk-bentuk konflik kepentingan yang ada selama ini. Sehingga subjek hukum dapat mengetahui dan memahami apa-apa saja larangan terhadap tindakan yang mengarah kepada konflik kepentingan. Dalam konteks kekinian, konflik kepentingan dipandang sebagai isu yang paling santer untuk didiskusikan, khususnya dalam upaya pencegahan tindak pidana korupsi. Karena konflik kepentingan sesungguhnya bukan hanya persoalan pemerintah Indonesia, melainkan seluruh negara di dunia. Hal ini dapat dilihat dari instrumen hukum internasional yang memberi perhatian serius terhadap fenomena konflik kepentingan, seperti United Nation Convention Against Corruption (UNCAC) dan International Code of Conduct for Public Official (ICCPO). Bahkan Organization for Economic Cooperation and Development (OECD) juga memiliki panduan bagaimana mengelola dan mencegah konflik kepentingan. Tiap-tiap regulasi tersebut tampaknya ada perbedaan cara melihat konflik kepentingan. UNCAC dan ICCPO melihat konflik kepentingan sebagai tangga menuju tindak pidana korupsi, sedangkan OECD melihat konflik kepentingan tidak selalu menjadi korupsi, melainkan lebih menekankan pada aspek ekonomi.

Dari pelbagai regulasi di atas memperlihatkan bahwa, baik Indonesia maupun dunia, pengendalian dan penanganan konflik kepentingan sudah sangat urgen untuk diatur terutama di kalangan institusi dan individu. Bagi institusi atau organisasi konflik kepentingan ini semata-mata untuk mencegah terjadinya praktik-praktik korupsi di kalangan penyelenggara negara dan korporasi yang

Beni Kurnia Illahi, Internalisasi Nilai Antikorupsi Melalui Pencegahan Dan Pengendalian Benturan Kepentingan Di Perguruan Tinggi 
Supremasi Hukum : Jurnal Penelitian Hukum

p-ISSN: 1693-766X ; e-ISSN: 2579-4663, Vol. 28, No. 2, Agustus 2019, 135-152

cenderung merugikan keuangan negara. Disamping itu, pengendalian konflik kepentingan juga merupakan bahagian dari upaya menciptakan kultur pelayanan publik yang baik, transparan, dan efisien tanpa mengurangi kinerja seorang penyelenggara negara berdasarkan prinsip good and clean governance. ${ }^{5}$

Sementara bagi individu, pengendalian konflik kepentingan merupakan wujud dalam rangka meningkatkan etos kerja guna menghasilkan kinerja yang baik dan maksimal serta bermanfaat bagi masyarakat. ${ }^{6}$ Poin pentingnya adalah bagaimana kemudian pengendalian dan pencegahan konflik kepentingan dari dini ini menjadi bahagian untuk menutup semua celah benih-benih korupsi baru. Sehingga pendidikan anti korupsi itu tidak hanya sekedar sosialisasi, melainkan bagaimana menumbuhkan karakter anti-korupsi itu dari hal-hal yang kecil seperti pengendalian konflik kepentingan. Sebab sebagaimana disinggung di awal, untuk saat ini mengindentifikasi sebuah konflik kepentingan itu memang sangat sulit, meskipun secara general kita sudah mulai menelusuri tipologi-tipologi dari konflik kepentingan tersebut. Karena konflik kepentingan dianggap sebagai kultur orang timur yaitu 'suka memberi sesuatu kepada seseorang yang sudah berjasa menolong', apalagi memiliki hubungan kekeluargaan atau pertemanan. Itu sebabnya, perlu jurang pemisah antara konflik kepentingan yang bernuansa positif dan negatif.

Untuk mengidentifikasi hal tersebut tentu saja kita perlu mengetahui sumber penyebab konflik kepentingan itu timbul. Pertama, tentu saja karena adanya kekuasaan dan kewenangan Penyelenggara Negara yang diperoleh dari peraturan perundang-undangan, baik itu bersumber dari atribusi, delegasi, maupun mandat. Kondisi ini dijelmakan dalam sebuah kredo klasik yang menyatakan bahwa kekuasaan yang berlebihan atau mutlak itu akan cenderung mengarah pada korupsi, sebagaimana yang pernah dilontarkan oleh Lord Acton yaitu "Power tends to corrupt, and absolute power corrupts absolutely". Kedua, adanya rangkap jabatan yang digunakan oleh Penyelenggara Negara untuk menduduki dua atau lebih jabatan publik sehingga tidak bisa menjalankan jabatannya secara profesional, independen dan akuntabel. Ketiga, karena adanya hubungan afiliasi yaitu hubungan yang dimiliki oleh seorang Penyelenggara Negara dengan pihak tertentu baik karena hubungan darah, hubungan perkawinan, maupun hubungan pertemanan yang dapat mempengaruhi keputusannya. Keempat, terdapatnya kelemahan sistem organisasi yaitu keadaan yang menjadi kendala bagi pencapaian tujuan pelaksanaan kewenangan penyelenggara negara yang disebabkan karena aturan, struktur dan budaya organisasi yang ada.

5 Inu Kencana Syafiie, Etika Pemerintahan, Dari Keseimbangan Good Governance dengan Clean Government Sampai pada State of The Art, Ilmu Pemerintahan dalam Mengubah Pemerintah Biadab menjadi Pemerintahan Beradab, Jakarta: Rineka Cipta, 2011, hlm.3.

6 Ermansjah Djaja, Memberantas Korupsi bersama KPK Kajian Yuridis Normatif UU Nomor 31 Tahun 1999 junto UU Nomor 20 Tahun 2001 Versi UU Nomor 30 Tahun 2002, Jakarta: Sinar Grafika 2008, hlm. 92-94.

Beni Kurnia Illahi, Internalisasi Nilai Antikorupsi Melalui Pencegahan Dan Pengendalian Benturan Kepentingan Di Perguruan Tinggi 
Supremasi Hukum : Jurnal Penelitian Hukum

p-ISSN: 1693-766X ; e-ISSN: 2579-4663, Vol. 28, No. 2, Agustus 2019, 135-152

Itu sebabnya persoalan konflik kepentingan perlu menjadi perhatian serius oleh seluruh kalangan. Kepuasaan masyarakat kepada pelayanan publik yang diberikan oleh pemerintah menjadi salah satu parameter penting untuk menilai keberhasilan pemerintah dalam menjalankan roda pemerintahan sesuai dengan amanat UUD NRI 1945 yakni memajukan kesejahteraan umum. Untuk mampu memberikan pelayanan publik yang prima, maka seyogyanya pemerintah harus mengacu dan mempedomani nilai-nilai etika dan kultur yang baik sebagai pelayan masyarakat. Tetapi faktanya pelayanan yang baik masih menjadi sesuatu barang langka. Masyarakat seringkali tidak merasakan suatu pelayanan publik yang mumpuni dari pemerintah baik yang dikarenakan faktor buruknya sistem birokrasi, keterbatasan sumber daya, praktik korupsi, kolusi dan nepotisme yang sebahagian hulunya itu dipicu oleh konflik kepentingan.

Sebab menurut Komisi Pemberantasan Korupsi Republik Indonesia ada 3 (tiga) tipe utama konflik kepentingan, yaitu: ${ }^{7}$

1. Actual conflict of interest, yaitu konflik kepentingan yang ada di antara tugas/ tanggung jawab resmi dan kepentingan pribadi (where a conflict exists between your official duties or responsibilities and your private interests);

2. Perceived conflict of interest, yaitu konflik kepentingan yang dipandang bercampur dengan tugas/tanggung jawab resmi yang nyatanya menjadi suatu kasus atau bukan (where it could be seen by others that your private interests could improperly interfere with or influence you in the performance of your official duties or responsibilities, whether or not this is in fact the case).

3. Potential conflict of interest, yaitu kepentingan pribadi bercampur dengan tugas/tanggung jawab resmi di masa mendatang (where your private interests could interfere with or influence your official duties or responsibilities in the future).

Menindaklanjuti dari tipe utama konflik kepentingan yang digagas oleh Komisi Pemberantasan Korupsi RI, maka menurut penulis ada 5 (lima) indikator bentuk penerapan kebijakan dalam rangka mengidentifikasi, mengelola, dan menyelesaikan situasi konflik kepentingan sebagaimana dikemukakan dalam skema berikut.

${ }^{7}$ Komisi Pemberantasan Korupsi, Pengelolaan Konflik Kepentingan, Jakarta: Komisi Pemberantasan Korupsi, 2009, hlm. 7.

Beni Kurnia Illahi, Internalisasi Nilai Antikorupsi Melalui Pencegahan Dan Pengendalian Benturan Kepentingan Di Perguruan Tinggi 
Skema 1.

Bentuk Penerapan Kebijakan untuk Menyelesaikan Konflik Kepentingan

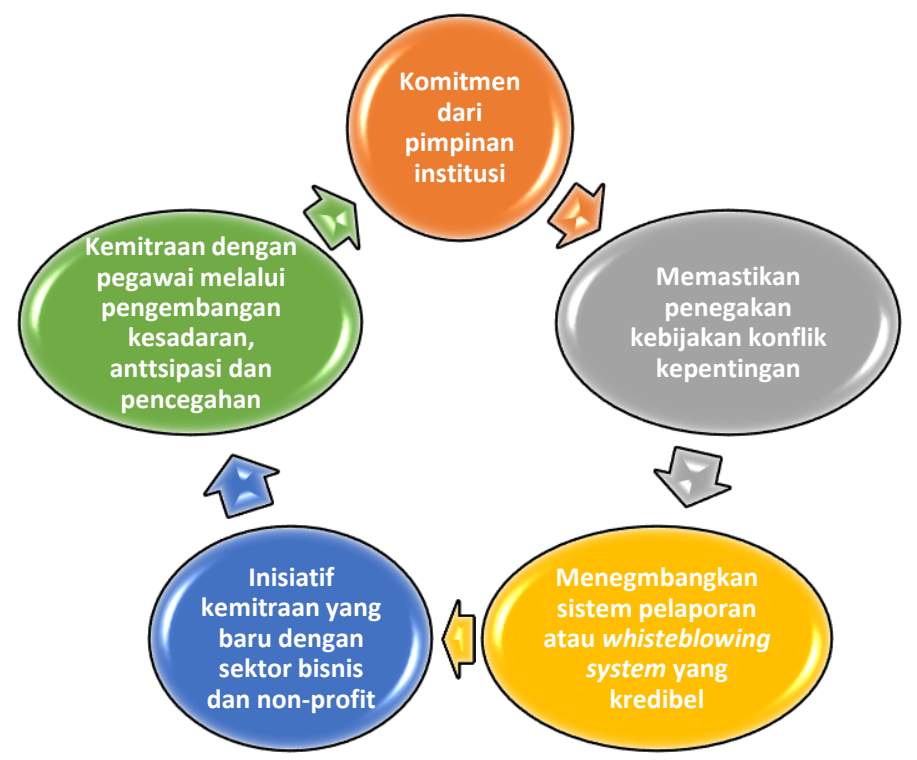

Berdasarkan skema gambar tersebut, konflik kepentingan sebetulnya tidak hanya persoalan hukum an sich, melainkan persoalan komitmen dari institusi baik pimpinan maupun bawahan. Serta membangun kemitraan yang baik sesama pegawai melalui pengembangan kesadaran, antisipasi dan pencegahan terhadap konflik kepentingan. Karena faktanya selama ini jika dilihat dari sistem pelaporan berjenjang dari bawah ke atas, seolah-olah semakin tinggi jabatannya, maka semakin bersih pula orangnya, padahal kasus-kasus korupsi yang mengemuka tersebut dapat kita lihat bahwa konflik kepentingan itu justru datang dari atas. Itu sebabnya, instrument hukum dan kode etik terhadap konflik kepentingan pada penyelenggara negara ini mesti dikelola dengan mereduksi indikator-indikator, sumber, bentuk, dan jenis dari konflik kepentingan tersebut.

\section{Internalisasi Nilai Antikorupsi Melalui Pencegahan dan Pengendalian Benturan Kepentingan di Perguruan Tinggi}

Fenomena konflik kepentingan di dunia pendidikan tinggi bukanlah suatu yang khas di Indonesia, melainkan kampus-kampus besar seperti Universitas Oxford, Universitas Newcastle dan Universitas Harvard juga sudah menggeluti ragam konflik kepentingan. Mereka sudah mengatur persoalan konflik kepentingan sejak awal tahun 2000an. Dalam konteks di Indonesia, sebetulnya sudah ada beberapa pimpinan perguruan tinggi yang menjadi tersangka atau terpidana kasus korupsi, seperti Rektor IAIN Pontianak (Prof. Dr. Hamka Siregar), mantan Rektor Universitas Airlangga (Fasichul Lisan), mantan Rektor Universitas Jambi (Prof Aulia Tasman), mantan Wakil Rektor UI (Tafsir Nurchamid), Wakil Rektor Universitas Maritim Raja Ali Haji (UMRAH) Tanjungpinang (Hery Suryadi), dll. Pertanyaan sederhananya adalah apakah kasus-kasus korupsi tersebut didahului atau diliputi oleh konflik kepentingan? Atau, apakah konflik kepentingan selalu menjadi pemicu kasus korupsi?

Beni Kurnia Illahi, Internalisasi Nilai Antikorupsi Melalui Pencegahan Dan Pengendalian Benturan Kepentingan Di Perguruan Tinggi 
Supremasi Hukum : Jurnal Penelitian Hukum

p-ISSN: 1693-766X ; e-ISSN: 2579-4663, Vol. 28, No. 2, Agustus 2019, 135-152

Secara holistik memang salah satu faktor pendorong munculnya tindak pidana korupsi itu adalah benturan atau konflik kepentingan, 8 akan tetapi menentukan sebuah perbuatan mengandung konflik kepentingan bukanlah suatu perkara yang mudah. Perlu irisan ataupun batasan instrument yang jelas dalam mengelola konflik kepentingan tersebut. Oleh karena itu upaya pencegahan dan pemberantasan tindak pidana korupsi dapat berjalan maksimal.

Dalam rangka pencegahan tindak pidana korupsi khususnya di jagat pendidikan tinggi, jika pengelolaan konflik kepentingan itu dikelola secara baik melalui penormaan hukum dan pendekatan secara etis, maka penyelenggara pimpinan perguruan tinggi, tenaga kependidikan, mahasiswa dan stakeholders terkait, dapat membaca dan memahami kapan suatu perbuatan itu dikatakan konflik kepentingan. Maka dari itu, pada hakikatnya konflik kepentingan itu belum tentu korupsi atau kecurangan, tetapi ia dapat memicu penyalahgunaan kewenangan untuk keuntungan pribadi dan mungkin mengandung potensi perilaku yang menyimpang. Artinya, dari polemik yang ada maka konflik kepentingan itu dapat dibagi menjadi dua bahagian, pertama konflik kepentingan yang bernuansa positif, dan kedua konflik kepentingan yang bernuansa negatif.

Pertanyaannya adalah kenapa ada istilah konflik kepentingan yang bernuansa positif. Dalam Teori Sosiologi Klasik yang dikenal dengan Teori Fungsionalis (Functionalist Theory) yang dikemukakan oleh William Ogburn menjelaskan bahwa semua bagian di masyarakat mempunyai kepentingan masingmasing dalam masyarakat lainnya untuk saling bekerjasama dalam membangun tatanan sosial yang stabil dan harmonis. ${ }^{9}$ Tentu saja pranata sosial ini tidak bisa dinafikan, karena semua orang memiliki kepentingan satu sama lain dalam rangka mewujudkan tujuannya atau kurang lebih sama dengan definisi politik. Sepanjang tidak ada motif yang memicu ke arah melawan hukum atau disebut juga dengan kepentingan yang bernuansa negatif, maka hal itu sah-sah saja. Namun demikian, yang menjadi catatan bahwa sampai saat ini pengertian dan definisi konflik kepentingan ini masih menjadi diskusi dan polemik pada tataran praktik penyelenggaraan pemerintahan di Indonesia. ${ }^{10}$ Layaknya definisi hukum, definisi konflik kepentingan sampai saat ini juga belum terdefinisi dan cenderung berbedabeda setiap peraturan perundang-undangan. Belum tersusunnya konsep dan definisi yang jelas menjadi alasan perlunya penataan terhadap konsep dalam penanganan konflik kepentingan di negeri ini.

Dalam konteks Indonesia sendiri sebetulnya di level undang-undang, Indonesia telah mengatur isu konflik kepentingan itu sejak era reformasi, mulai Undang-Undang Nomor 28 Tahun 1999, Undang-Undang Nomor 31 Tahun 1999,

8 Arsyad, Jawade Hafidz Arsyad., Korupsi dalam Perspektif Hukum Administrasi Negara, Jakarta: Sinar Grafika, 2013, hlm. 34.

9 Soejono Soekanto, Pokok-Pokok Sosiologi Hukum, Jakarta: Raja Grafindo Persada, 2010, hlm.77

10Komisi Pemberantasan Korupsi, Korupsi, Panduan Penanganan Konflik Kepentingan Bagi Penyelenggara Negara, Jakarta: Komisi Pemberantasan Korupsi, 2009, hlm. iv

Beni Kurnia Illahi, Internalisasi Nilai Antikorupsi Melalui Pencegahan Dan Pengendalian Benturan Kepentingan Di Perguruan Tinggi 
Supremasi Hukum : Jurnal Penelitian Hukum

p-ISSN: 1693-766X ; e-ISSN: 2579-4663, Vol. 28, No. 2, Agustus 2019, 135-152

Undang-Undang Nomor 7 Tahun 2006 hingga Undang-Undang Nomor 8 Tahun 1974 jo Undang-Undang Nomor 43 Tahun 1999, Undang-Undang Nomor 30 Tahun 2002, Undang-Undang Nomor 5 Tahun 2014 hingga Undang-Undang Nomor 30 Tahun 2014.

Meskipun regulasi konflik kepentingan ini sudah diatur di level undangundang, akan tetapi sampai saat ini masih terdapat celah (loop hole) dan kelemahan-kelemahan dalam penerapan. Misalnya, sebagaimana yang disinggung di bagian awal, bahwa persoalan pokoknya adalah belum adanya definisi yang sama soal konflik kepentingan, selain itu konflik kepentingan tersebut masih memiliki ruang lingkup sempit karena dibatasi oleh objek instansi yang berhubungan undang-undang tersebut, sehingga undang-undang tersebut hanya mengikat ke dalam tidak ke luar. Di samping itu, fokus pencegahan terhadap konflik kepentingan hari ini hanya terpusat pada penyelenggaraan pemerintahan.

Lalu setelah dicermati, selain konflik kepentingan ini berkaitan erat dengan persoalan kultur dan kalau dalam istilah syariah islam lebih berkontempelasi ke arah syubhat, penulis kemudian berhipotesa bahwa pengaturan terkait konflik kepentingan ini sebetulnya masih ber-evolusi tertatih-tatih menuju ke arah tujuan yang sesungguhnya. Hal ini dapat dilihat, pada mulanya konflik kepentingan itu hanya diatur sebagai bahagian dari kode etik, kemudian pengaturan tersebut semakin lengkap mulai definisi, latar belakang, kewajiban pejabat yang terlibat konflik kepentingan dan implikasi konflik kepentingan terhadap status pejabat maupun setiap keputusan yang dikeluarkan oleh pejabat yang bersangkutan.

Ironisnya, pada saat yang sama di tengah persoalan korupsi di negeri ini semakin menggurita, ternyata betul ujung pangkal dari perbuatan tersebut dipicu dan berawal dari sebuah konflik kepentingan. Berangkat dari contoh kasus korupsi di beberapa perguruan tinggi yang didalangi yang dilakukan oleh Mohammad Nazaruddin. Ia adalah seorang anggota DPR, bendahara partai politik, dan pengusaha. Modusnya adalah ia menggunakan kewenangannya sebagai anggota DPR untuk menjaring aspirasi masyarakat, dalam bentuk proposal pengadaan barang, kemudian proposal tersebut diajukan kepada Menteri terkait, terutama yang berasal dari partai politik yang sama dengan dia. Ketika proposal tersebut disetujui, perusahaan yang harus menang tender adalah perusahaan milik Nazaruddin sendiri. Selain itu, penerima proyek harus menyetor fee proyek kepada Nazaruddin. Uang-uang tersebut disetorkan kepada partai politik. Itu salah satu contoh konflik kepentingan yang berujung korupsi yang pernah terjadi di beberapa perguruan tinggi.

Dari satu kasus di atas, maka kita dapat menganalisis bahwa konflik kepentingan itu muncul ketika komitmen dan tanggungjawab anggota universitas di dalam kampus dikompromikan dengan komitmen dan tanggungjawab di luar kampus seperti dengan lembaga donor, keluarga, hubungan personal. Konflik kepentingan tidak selalu tampak jelas, karenanya pada saat mengevaluasi potensi konflik kepentingan, anggota universitas perlu mempertimbangkan bagaimana konflik kepentingan itu dipahami oleh orang lain, karena penampakan atau pemahaman tentang konflik kepentingan sama membahayakannya dengan konflik kepentingan itu sendiri.

Beni Kurnia Illahi, Internalisasi Nilai Antikorupsi Melalui Pencegahan Dan Pengendalian Benturan Kepentingan Di Perguruan Tinggi 
Supremasi Hukum : Jurnal Penelitian Hukum

p-ISSN: 1693-766X ; e-ISSN: 2579-4663, Vol. 28, No. 2, Agustus 2019, 135-152

Misalnya sebagaimana yang terjadi di Universitas Andalas, di mana sebagai kampus tertua di luar Pulau Jawa Universitas Andalas ternyata masih mengalami kondisi dan suhu koruptif. Barangkali, yang menjadi sorotan di kampus Universitas Andalas beberapa tahun terakhir ini adalah soal pola Penerimaan Mahasiswa Baru yang diselenggarakan tiap tahunnya. Menurut Pasal 73 ayat (1) UU Nomor 12 Tahun 2012 tentang Pendidikan Tinggi menjelaskan bahwa Penerimaan Mahasiswa baru PTN untuk setiap Program Studi dapat dilakukan melalui pola penerimaan mahasiswa secara nasional dan bentuk lain.

Pola penerimaan mahasiswa sebagaimana dijelaskan dalam UU Nomor 12 Tahun 2012 kemudian diakomodir di dalam Pasal 2 Peraturan Menteri Riset, Teknologi, dan Pendidikan Tinggi RI Nomor 126 Tahun 2016 tentang Penerimaan Mahasiswa Baru Program Sarjana Pada Perguruan Tinggi Negeri. Di mana, Pasal 2 tersebut mengamanatkan bahwa Pola Penerimaan Mahasiswa Baru Program Sarjana pada PTN dilakukan melalui:

a. SNMPTN (Seleksi Nasional Masuk Perguruan Tinggi Negeri) yang dilakukan melalui seleksi berdasarkan hasil penelusuran prestasi akademik calon mahasiswa;

b. SBMPTN (Seleksi Bersama Masuk Perguruan Tinggi Negeri) yang dilakukan melalui seleksi berdasarkan hasil ujian tertulis dalam bentuk cetak (paper based testing) atau menggunakan komputer (computer based testing), atau kombinasi hasil ujian tertulis dan ujian keterampilan calon mahasiswa; dan

c. Seleksi Mandiri dilakukan melalui seleksi yang diatur dan ditetapkan oleh masing-masing PTN.

Setelah diamati dari pola penerimaan mahasiswa baru tersebut, persoalan yang terjadi di Universitas Andalas adalah ditemukannya kejanggalan dalam Pola Seleksi Mandiri. Di mana, setelah dikalkulasikan dari besaran persentase daya tampung setiap program studi di Universitas Andalas ditemukan adanya penambahan kuota sebesar 3,2\% (tiga koma dua persen) dari masing-masing program studi yang sudah ditentukan jumlahnya. Anehnya, penambahan kuota dimaksud tidak disertai dengan pemberitahuan atau pengumuman secara resmi dan terbuka oleh pimpinan Perguruan Tinggi dan Panitia Penyelenggaran Ujian. Ditambah lagi tidak adanya pertimbangan dan alasan yang logis oleh Perguruan Tinggi terhadap penambahan kuota daya tampung dari masing-masing program studi tersebut.

Secara kasat mata, kebijakan ini seakan tidak transparan dan ditutupi oleh pihak perguruan tinggi. Namun, kemudian setelah dikonsolidasikan dan ditelusuri kepada pihak rektorat Universitas Andalas, Pimpinan menyampaikan dan mengakui bahwa, "kita memang ada melakukan penambahan kuota dalam bentuk persentase pada masing-masing program studi. Dan penambahan tersebut yaa tidak lebih dari 5\% (lima persen) kita lakukan".

Pernyataan Pimpinan Universitas Andalas tersebut membuat kita berfikir, bahwa seakan-akan hukum dan aturan tersebut bisa dikesampingkan begitu saja dan memang dianggap tidak ada. Aturan-aturan tersebut bisa saja diterobos demi mendapatkan keuntungan dan mementingkan kepentingan pribadi maupun

Beni Kurnia Illahi, Internalisasi Nilai Antikorupsi Melalui Pencegahan Dan Pengendalian Benturan Kepentingan Di Perguruan Tinggi 
Supremasi Hukum : Jurnal Penelitian Hukum

p-ISSN: 1693-766X ; e-ISSN: 2579-4663, Vol. 28, No. 2, Agustus 2019, 135-152

sekelompok orang. Adapun, jika kita melihat dari kalkulasi olahan data menjelaskan bahwa ada kelebihan uang dari penambahan besaran kuota masing program studi tersebut sebesar Rp. 2.463.500.000,- (Dua Milyar Empat Ratus Juta Enam Puluh Tiga Juta Lima Ratus Ribu Rupiah). Bayangkan, nilai dua milyar lebih ini jika kita setarakan maka dapat dialokasikan untuk beasiswa bagi mahasiwa yang tidak mampu.

Tentu saja pertanggungjawaban keuangan terhadap penerimaan mahasiswa baru di Universitas Andalas ini tidak sesuai dengan ketentuan Pasal 5 ayat (4) Permenristekdikti Nomor 126 Tahun 2016 yang menjelaskan bahwa, daya tamping setiap program studi yang disediakan untuk calon mahasiswa baru yang mengikuti Seleksi Mandiri ditetapkan paling banyak 30\% (tiga puluh persen) dari daya tampung program studi yang bersangkutan. Karena adanya kelebihan 3,2\% (tiga koma dua persen) dari daya tamping program studi. Kebijakan seperti ini akan membuka ruang bisnis gelas pada perguruan tinggi negeri di Indonesia, sehingga akan banyak praktik-praktik suap dan nepotisme yang terjadi di Perguruan Tinggi.

Padahal dalam Pasal 73 ayat (5) UU Nomor 12 Tahun 2012 tegas menjelaskan bahwa Penerimaan Mahasiswa baru Perguruan Tinggi merupakan seleksi akademis dan dilarang dikaitkan dengan tujuan komersial. Hal tersebut diperkuat dengan prinsip-prinsip sebagaimana yang tertuang dalam Pasal 3 Permenristekdikti Nomor 126 Tahun 2016 yang mengamanatkan bahwa, pola penerimaan mahasiwa baru harus diselenggarakan dengan prinsip :

a. Adil, yaitu tidak membedakan agama, suku, ras, jenis kelamin, umur, kedudukan sosial, kondisi fisik, dan tingkat kemampuan ekonomi calon mahasiswa, dengan tetap memperhatikan potensi dan prestasi akademik calon mahasiswa dan kekhusuan Program Studi di Perguruan Tinggi yang bersangkutan;

b. Akuntabel, yaitu dilaksanakan sesuai dengan prosedur dan kriteria yang jelas; dan

c. Transparan, yaitu pelaksanaan penerimaan dilakukan secara terbuka dan hasil pelaksanaan dapat diakses oleh semua pihak secara mudah.

Dari kasus di atas dapat ditelaah bahwa perguruan tinggi sebagai corong penghasil sarjana masih belum menganggap pendidikan sebagai tujuan dari konstitusi yaitu mencedaskan kehidupan bangsa. Perguruan tinggi seakan leluasa dan bebas menerapkan pola penerimaan mahasiswa baru. Hal tersebut ditampik adanya Pasal 12 Peraturan Menteri Riset, Teknologi, Dan Pendidikan Tinggi Republik Indonesia Nomor 27 Tahun 2017 Tentang Perubahan Atas Peraturan Menteri Riset, Teknologi, Dan Pendidikan Tinggi Nomor 126 Tahun 2016 Tentang Penerimaan Mahasiswa Baru Program Sarjana Pada Perguruan Tinggi Negeri yang menjelaskan ketentuan mengenai persyaratan, metode, tata cara, dan kriteria seleksi penerimaan mahasiswa baru program sarjana secara mandiri yang dilaksanakan oleh masing-masing PTN diatur dan ditetapkan oleh PTN sesuai dengan ketentuan peraturan perundang-undangan.

Beni Kurnia Illahi, Internalisasi Nilai Antikorupsi Melalui Pencegahan Dan Pengendalian Benturan Kepentingan Di Perguruan Tinggi 
Supremasi Hukum : Jurnal Penelitian Hukum

p-ISSN: 1693-766X ; e-ISSN: 2579-4663, Vol. 28, No. 2, Agustus 2019, 135-152

Sebetulnya dengan adanya frasa "sesuai dengan ketentuan peraturan perundang-undangan", seharusnya Rektor mengacu kepada Peraturan Perundangundangan yang lebih tinggi dalam menerapkan kebijakan internal di Perguruan Tinggi, tidak melakukan hal yang bertentangan dan melakukan penerobosan hukum. Konflik kepentingan seperti ini harus segera diatur melalui instrument hukum yang kuat beserta sanksi yang akan dijatuhkan kepada siapa saja yang terlibat. Jika tidak, Perguruan Tinggi akan menjadi ajang komersialisasi bagi aparatur yang selalu menggerogoti uang rakyat dan juga berefek terhadap penurunan kualitas pendidikan di Indonesia.

Dari aspek norma dan penegakan hukum tampaknya Permenristekdikti Nomor 58 Tahun 2016 tentang Penanganan Benturan Kepentingan belum mampu mengakomodir secara utuh setiap persoalan yang memicu korupsi yang disebabkan oleh konflik kepentingan di perguruan tinggi. artinya norma tersebut tidak bertolak dari kompleksitas persoalan korupsi pada dunia pendidikan tinggi, yang sangat mungkin diawali atau diliputi oleh konflik kepentingan. Hal ini dapat dilihat dari sistem pelaporan berjenjang dari bawah ke atas, seolah-olah semakin tinggi jabatannya maka semakin bersih orangnya, padahal kasus-kasus korupsi yang mengemuka dapat kita lihat bahwa konflik kepentingan justru dari atas.

Berdasarkan hal tersebut menurut penulis ada tiga dimensi utama konflik kepentingan yang dipertimbangkan. Pertama, dimensi peran dan hubungan. Konflik kepentingan secara umum muncul dari peran atau aktivitas dan melibatkan pihak-pihak di luar universitas, peran yang diambil anggota universitas di luar kampus, peran ganda staf dan mahasiswa di dalam kampus, keanggotaan komite dan peran pengambilan keputusan atas nama universitas, departemen, fakultas dan unit-unit lainnya, hubungan personal khusus.

Kedua, dimensi aktivitas yang meningkatkan potensi konflik kepentingan. Konflik kepentingan dapat muncul dari perusahaan-perusahaan di mana staf dan mahasiswa memiliki kepentingan, hak atas kekayaan intelektual, pengadaan barang/jasa; transaksi komersial yang kompleks, penelitian bersama lembaga donor; kesepakatan dan aktivitas eksternal; penerimaan mahasiswa dan rekrutmen pegawai.

Ketiga, dimensi financial dan non-finansial. Konflik kepentingan dapat berbentuk finansial, non-finansial atau gabungan keduanya. Konflik kepentingan terkait financial muncul jika ada keuntungan financial yang mempengaruhi tindakan seseorang dan ketika mereka memiliki peluang untuk mempengaruhi kebijakan universitas. Keuntungan financial mencakup upah, hadiah/pelayanan, penghapusan hutang, diskon, bonus, saham, hak atas kekayaan intelektual. Kewajiban deklarasi konflik kepentingan tidak ditentukan besarnya keuntungan financial yang diterima. Keuntungan non-finansial misalnya peluang karir atau pendidikan lebih tinggi, hubungan personal.

Pertanyaannya adalah bagaimana cara mengidentifikasi potensi konflik kepentingan tersebut. Artinya Staf dan mahasiswa harus mempertimbangkan untuk siapa mereka bertindak dan apakah ada pertentangan motivasi atau kepentingan yang dapat mempengaruhi mereka. Deklarasi konflik kepentingan

Beni Kurnia Illahi, Internalisasi Nilai Antikorupsi Melalui Pencegahan Dan Pengendalian Benturan Kepentingan Di Perguruan Tinggi 
Supremasi Hukum : Jurnal Penelitian Hukum

p-ISSN: 1693-766X ; e-ISSN: 2579-4663, Vol. 28, No. 2, Agustus 2019, 135-152

dilakukan secara berjenjang, misalnya jika staf atau mahasiswa yang melakukan deklarasi, maka surat pernyataan konflik kepentingan diajukan kepada Kepala Departemen, jika Kepala Departemen yang membuat deklarasi maka surat pernyataan diajukan kepada pejabat yang lebih tinggi.

Selain deklarasi, penyelesaian konflik kepentingan dilakukan dengan cara tidak terlibat diskusi terkait persoalan yang berpotensi konflik kepentingan, tidak terlibat pengambilan keputusan, menyerahkan kepada pihak lain untuk mengambil keputusan, tidak menyerahkan penyelesaian konflik kepentingan mahasiswa kepada supervisornya, menyetorkan keuntungan financial kepada lembaga yang terpercaya, mempublikasikan catatan kepentingan, mendeklarasikan kepentingan kepada sponsor atau pihak ketiga, tidak terlibat dalam proyek-proyek tertentu, pejabat-pejabat universitas menyampaikan laporan berkala tentang deklarasi konflik kepentingan kepada Komite Konflik Kepentingan.

Berdasarkan kondisi dan deskripsi yang sudah penulis rumuskan dalam bab di atas, maka berikut 10 (sepuluh) poin gagasan yang dapat ditawarkan dalam rangka memperkuat dan menyempurnakan pelbagai regulasi dalam rangka mencegah dan membangun konsep pengelolaan konflik kepentingan di Indonesia :

1. Menyusun kerangka kebijakan penanganan konflik kepentingan di level perguruan tinggi bagi setiap lembaga Negara baik vertical maupun horizontal;

2. Mengidentifikasi secara detail setiap tipologi konflik kepentingan di perguruan tinggi yang memicu praktik koruptif di kalangan penyelenggara Negara;

3. Membangun komitmen di kalangan pimpinan perguruan tinggi dalam penerapan kebijakan konflik kepentingan melalui monitoring dan evaluasi pada setiap sumber kewenangan yang diberikan kepada penyelenggara Negara;

4. Membangun etika, moral, dan kultur anti korupsi bagi setiap civitas akademika perguruan tinggi untuk tidak terlibat dalam kegiatan konflik kepentingan;

5. Perlunya deklarasi konflik kepentingan bagi segenap pimpinan perguruan tinggi dan civitas akademika melalui pernyataan awal dan pelaporan perihal adanya kepentingan pribadi yang dapat bertentangan dengan pelaksanaan jabatannya yang mencakup informasi yang rinci untuk bisa menentukan tingkat konflik kepentingan dan bagaimana menanganinya;

6. Meningkatkan pengawasan baik preventif maupun represif setiap konflik kepentingan di perguruan tinggi yang mengarah kepada gratifikasi, hubungan afiliasi politik, ketidakwaran dalam pengadaan barang dan jasa, pengangkatan suatu jabatan yang sarat akan politik, rangkap jabatan, dan tindakan koruptif lainnya;

7. Setiap pengambil kebijakan hendaknya dapat membuka peta perizinan pada setiap izin yang dikeluarkan, sehingga semua orang dapat mengetahui afiliasi perizinan ketika suatu waktu terjadi konflik kepentingan antara pihak perguruan tinggi dengan pihak terkait;

Beni Kurnia Illahi, Internalisasi Nilai Antikorupsi Melalui Pencegahan Dan Pengendalian Benturan Kepentingan Di Perguruan Tinggi 
8. Membangun sistem informasi yang terbuka dan akuntabel bagi perguruan tinggi dalam setiap menjalankan fungsi dan kewenangannya, sehingga mahasiswa dan masyarakat sebagai orang yang menikmati pelayanan publik mengetahui seberapa jauh kinerja pemerintah untuk masyarakatnya;

9. Mewujudkan penegakan kebijakan konflik kepentingan di perguruan tinggi yang efektif dengan membentuk sistem pengaduan yang bersifat independen dan mekanisme identifikasi untuk mendeteksi setiap kebijakan yang mengarah pada konflik kepentingan, memperbaharui secara berkala instrument konflik kepentingan, serta menerapkan sanksi yang tegas dan memadai bagi setiap pelanggar yang terbukti melakukan konflik kepentingan berdasarkan peraturan perundang-undangan;

10. Menciptakan dan membangun perspektif kepada masyarakat terhadap setiap konflik kepentingan yang terjadi di lingkungan perguruan tinggi, sehingga seluruh stakeholders di perguruan tinggi dapat mengawasi dan melaporkan ketika mengetahui dan melihat tindakan konflik kepentingan.

\section{PENUTUP}

Pencegahan dan pengendalian konflik kepentingan sudah menjadi fokus serius bagi seluruh penyelenggara negara termasuk aparat penegak hukum. Karena konflik kepentingan ini ibarat 'tindakan pemula seseorang' yang ingin mencoba masuk ke lubang perbuatan menyimpang seperti korupsi. Melalui pendekatan peraturan perundang-undangan diharapkan kebijakan ini menjadi tools dan sarana alternatif dalam pengawasan penyelenggaraan pemerintahan. Disamping itu, pendekatan melalui instrument kode etik juga bahagian yang tidak bisa terpisahkan dalam merumuskan suatu norma tersebut. Dengan merinci dan mengidentifikasi setiap modus operandi dan karakteristik tindakan konflik kepentingan maka penyelenggara Negara akan lebih berhati-hati dalam bertindak dan menjalankan fungsi serta kewenangannya. Disamping itu, Permenristekdikti Nomor 58 Tahun 2016 tampaknya juga belum tersosialisasi secara baik dan massif ke kampus-kampus, sehingga perlu disosialisakan sekaligus melihat konteks persoalan setiap kampus sebagai bahagiaan dalam internalisasi nilai-nilai antikorupsi untuk seluruh kalangan Perguruan Tinggi di Indonesia.

\section{DAFTAR PUSTAKA}

Arsyad, Jawade Hafidz., 2013, Korupsi dalam Perspektif Hukum Administrasi Negara, Jakarta: Sinar Grafika.

Djaja, Ermansjah., 2008, Memberantas Korupsi bersama KPK Kajian Yuridis Normatif UU Nomor 31 Tahun 1999 junto UU Nomor 20 Tahun 2001 Versi UU Nomor 30 Tahun 2002, Jakarta: Sinar Grafika.

Beni Kurnia Illahi, Internalisasi Nilai Antikorupsi Melalui Pencegahan Dan Pengendalian Benturan Kepentingan Di Perguruan Tinggi 
Supremasi Hukum : Jurnal Penelitian Hukum

p-ISSN: 1693-766X ; e-ISSN: 2579-4663, Vol. 28, No. 2, Agustus 2019, 135-152

Indonesia Corruption Watch, Penerapan Unsur Merugikan Keuangan Negara Dalam Delik Tindak Pidana Korupsi, Jakarta: Indonesia Corruption Watch,2014, hlm. 3

Indonesia, Transparency International., 2018, Naskah Akademik Peraturan Menteri Riset, Teknologi, dan Pendidikan Tinggi tentang Pencegahan dan Pengendalian Konflik Kepentingan di Perguruan Tinggi Negeri, Jakarta: Transparency International Indonesia.

Korupsi, Komisi Pemberantasan., 2009, Pengelolaan Konflik Kepentingan, Jakarta: Komisi Pemberantasan Korupsi.

Korupsi, Komisi Pemberantasan., 2009, Panduan Penanganan Konflik Kepentingan Bagi Penyelenggara Negara, Jakarta: Komisi Pemberantasan Korupsi.

Permenristekdikti Nomor 58 Tahun 2016 tentang Pedoman Penanganan Benturan Kepentingan Di Lingkungan Kementerian Riset, Teknologi, Dan Pendidikan Tinggi.

Peraturan Menteri Riset, Teknologi, Dan Pendidikan Tinggi Republik Indonesia Nomor 27 Tahun 2017 Tentang Perubahan Atas Peraturan Menteri Riset, Teknologi, Dan Pendidikan Tinggi Nomor 126 Tahun 2016 Tentang Penerimaan Mahasiswa Baru Program Sarjana Pada Perguruan Tinggi Negeri

Soekanto, Soerjono., 2005, Faktor-Faktor yang Mempengaruhi Penegakan Hukum, Jakarta: Raja Grafindo Persada.

Soekanto, Soerjono., 2010, Pokok-Pokok Sosiologi Hukum, Jakarta: Raja Grafindo Persada.

Susanti, Laras., 2016, Bunga Rampai Makalah Anti Corruption Summit 2016, Yogyakarta: Pusat Kajian Anti Korupsi (PUKAT Korupsi) Universitas Gadjah Mada.

Syafiie, Inu Kencana., 2011, Etika Pemerintahan, Dari Keseimbangan Good Governance dengan Clean Government Sampai pada State of The Art, Ilmu Pemerintahan dalam Mengubah Pemerintah Biadab menjadi Pemerintahan Beradab, Jakarta: Rineka Cipta.

Undang-Undang Dasar Negara Kesatuan Republik Indonesia Tahun 1945

Beni Kurnia Illahi, Internalisasi Nilai Antikorupsi Melalui Pencegahan Dan Pengendalian Benturan Kepentingan Di Perguruan Tinggi 
Supremasi Hukum : Jurnal Penelitian Hukum

p-ISSN: 1693-766X ; e-ISSN: 2579-4663, Vol. 28, No. 2, Agustus 2019, 135-152

Undang-Undang Republik Indonesia Nomor 28 Tahun 1999 Tentang Penyelenggaraan Negara Yang Bersih Dan Bebas Dari Korupsi, Kolusi, Dan Nepotisme

Undang-Undang Republik Indonesia Nomor 12 Tahun 2012 Tentang Pendidikan Tinggi

Undang-Undang Nomor 5 Tahun 2014 Tentang Aparatur Sipil Negara

Beni Kurnia Illahi, Internalisasi Nilai Antikorupsi Melalui Pencegahan Dan Pengendalian Benturan Kepentingan Di Perguruan Tinggi 